\title{
タイル張り仕上げの剥離防止性能評価に関する研究 RESEARCH ON PERFORMANCE EVALUATION METHOD OF FINISHING TILE BONDING
}

\author{
起 橋 孝徳*, 桝 田佳 寛**, 河野政 典*** \\ Takanori OKIHASHI, Yoshihiro MASUDA and Masanori KONO
}

\begin{abstract}
The influence by the testing time was examined about the shrinkage compliance examination of tiled finish. As a result, the shrinkage compliance examination and the value of the destruction point with short loading time is found to show better performance than the case where the shrinkage progresses over a long period of time. Moreover, it proposed the method of evaluating the decrease of tile adhesion from the result of the shrinkage compliance examination. And, it was clarified that the decrease tendency of the bond strength of the tile finish can be estimated by using the proposed shrinkage transmission remaining rate.
\end{abstract}

Keywords : tile, direct bonding, tracking of strain, creep, adhesive strength, drying shrinkage タイル，直張り，ひずみ追従性，クリープ，接着強度，乾燥収縮

\section{1.はじめに}

タイル張り仕上げは、剥離・剥落を生じることが問題となってお り、タイル張りの安全性に関する評価方法が求められている。タイ ル張り仕上げの剥離は、施工時に十分な接着強度を確保している部 位でも生じることがある。このため、従来行われてきた接着強度の 管理では、接着不良の有無については評価できるが、タイル張り仕 上げの経年による剥離の危険度を評価することは難しい。

既往の研究 1)では、タイル張り仕上げの経年による剥離は、タイ ルと下地コンクリートの間のひずみ差によって生じることが指摘さ れており、このひずみ差をタイル張り仕上げを施した試験体に強制 的に与える「ひずみ追従性試験」による研究が行われている2) 7)なと。 しかし、これらは一部に繰り返し載荷を行ったもの 5),6)があるもの の、ほとんどは短期間の試験であり、いずれの試験でも与えられる ひずみの進行は実際の建物に比べて著しく速いため、下地コンクリ ートの乾燥収縮やクリープ等によって長期的に漸増するひずみがタ イル張り仕上げに及ぼす影響を正しく評価できていない恐れがある。 本研究では、下地コンクリートのひずみが徐々に進行する場合の タイルの挙動について実験的検討を行ってひずみ追従性試験と比較 し、載荷速度による相違を把握した。また、下地コンクリートのひ ずみの増大に伴ってタイルの下地追従性が低下した後のタイルの接 着性能について、ひずみの計測值を用いた新たな評価方法を提案す るとともに、接着強度との関係を明らかにした。

\section{2.ひずみ追従性試験の載荷速度による影響}

\section{1 実験目的}

タイル仕上げの剥離防止性能の評価に際して、既往の研究で行わ
れているひずみ追従性試験は、載荷時間が短く載荷速度が速いため に本来より高いひずみ追従性能を示寸恐れがある。そこで、載荷速 度の違いによる影響を把握することを目的とした実験を行った。

\section{2 実験概要}

通常行われているひずみ追従性試験は、荷重の増大によってひず みを進行させている。これに対して、継続して作用する一定荷重と 乾燥によってひずみが徐々に進行する場合の、タイルと下地コンク リートのひずみを計測する実験（以下、クリープ追従性試験と称す） を行った。また、同時に製作した試験体を用いて、短時間のひずみ 追従性試験を行ってタイルと下地コンクリートのひずみの関係を比 較し、載荷速度の影響について検討した。実験要因と水準を表 1 に 示す。試験体は 6 体製作し、このうち 3 体（No.1～No.3）をクリー プ追従性試験に、残りの 3 体（No.4〜No.6）をクリープ追従性試験 期間中の乾燥収縮計測とひずみ追従性試験に使用した。ひずみ追従 性試験の載荷時期はクリープ追従性試験終了時とし、載荷開始前の 試験体は、クリープ追従性試験と並行して無載荷状態における乾燥 収縮ひずみの計測を行った。なお、ここで使用した試験体はひずみ 計測の後に、後述する 3.3 の接着強度試験に供する。

表 1 実験要因と水準

\begin{tabular}{|c|c|c|}
\hline 試験名称 & 載荷方法 & 下地処理 \\
\hline \multirow{2}{*}{$\begin{array}{c}\text { クリープ } \\
\text { 追従性試験 } \\
\text { 試験体 No.1〜3 }\end{array}$} & \multirow{2}{*}{$\begin{array}{c}\text { 載荷荷重: } 108 \mathrm{kN}(\text { 一定 }) \\
\text { 軸力比: } 1 / 3 \sigma \mathrm{B} \\
3 \text { 力月間継続載荷 }\end{array}$} & 下地処理なし(NT) \\
\hline & & 超高圧水洗浄(HW) \\
\hline \multirow{2}{*}{$\begin{array}{c}\text { ひずみ } \\
\text { 追従性試験 } \\
\text { 試験体 No.4〜6 }\end{array}$} & \multirow{2}{*}{$\begin{array}{c}\text { 載荷荷重: } 350 \mathrm{kN} \text { (最大) } \\
\text { 軸力比: } 1 / 1 \sigma \mathrm{B} \\
3 \text { 力月気中養生後短期載荷 }\end{array}$} & 下地処理なし(NT) \\
\hline & & 超高圧水洗浄(HW) \\
\hline
\end{tabular}

\footnotetext{
* 陎奥村組技術研究所

** 宇都宮大学工学研究科 教授. 工博

*** (侏)奥村組技術研究所 博士 (工学)
}

Technical Research Institute, Okumura Corporation

Prof., Dept. of Design and Engineering for Global Environment, Architecture Course, Utsunomiya Univ., Dr. Eng.

Technical Research Institute, Okumura Corporation, Dr. Eng. 
試験体に使用した材料を表 2 に、コンクリートの調合を表 3 に示 す。下地コンクリートの呼び強度は $27 \mathrm{~N} / \mathrm{mm}^{2}$ とした。標準水中養 生におけるコンクリート供試体（ $\phi 100 \times 200 \mathrm{~mm} ）$ の強度は、材齢 28 日で $32.1 \mathrm{~N} / \mathrm{mm}^{2} 、 91$ 日では $36.0 \mathrm{~N} / \mathrm{mm}^{2}$ であった。

試験体の下地処理方法とタイル割付を図 1 に示す。試験体のタイ ル張りは、コンクリートを $10 \times 10 \times 32 \mathrm{~cm}$ の鋼製型枠に打設した際 の側面に当たる長辺 2 面に行った。下地処理は、各試験体の片面で は水洗い以外の下地処理を行わず（NT : Non Treatment）、別の片 面にはコンクリートの材齢 2 週間目に水圧 $100 \mathrm{MPa}$ の超高圧水洗浄 処理を施し (HW : High pressure Water treatment)、1体の試験 体の表裏で下地処理の有無による比較を行うこととした。タイルの 張り付けはコンクリートの材齢 4 週間目に行い、張付材料には既調 合モルタルを使用した。乾燥収縮試験やクリープ追従性試験の載荷

\section{表 2 使用材料}

\begin{tabular}{|c|c|c|}
\hline \multicolumn{2}{|c|}{ 材料種類 } & 諸元 \\
\hline \multirow{4}{*}{$\begin{array}{l}コ \\
\text { ン } \\
\text { ク } \\
\text { リ } \\
1 \\
\text { 卜 }\end{array}$} & セメント & 普通ポルトランドセメント、密度 : $3.16 \mathrm{~g} / \mathrm{cm}^{3}$ \\
\hline & 細骨材 & $\begin{array}{l}\text { 千葉県富津産山砂、表乾密度 : } 2.60 \mathrm{~g} / \mathrm{cm}^{3} 、 \\
\text { 吸水率 : } 1.27 \%\end{array}$ \\
\hline & 粗骨材 & $\begin{array}{l}\text { 桜川産砕石、表乾密度 : } 2.65 \mathrm{~g} / \mathrm{cm}^{3} 、 \\
\text { 吸水率 : } 0.62 \% \text { 、実積率 : } 61.5 \%\end{array}$ \\
\hline & 混和剤 & A E 減水剤 \\
\hline \multirow{3}{*}{$\begin{array}{l}\text { 仕 } \\
\text { 上 } \\
\text { ル }\end{array}$} & タイル & $\begin{array}{l}\text { 陶磁器質タイル (JIS A 5209(2008)吸水率に } \\
\text { よる区分 I 類)、裏足有、45 角二丁 }\end{array}$ \\
\hline & 張付材 & タイル張付け用プレミックスモルタル \\
\hline & 目地材 & タイル化粧目地材 \\
\hline
\end{tabular}

表 3 コンクリート調合

\begin{tabular}{|c|c|c|c|c|c|}
\hline $\begin{array}{c}\text { 水セメ゙ト比 } \\
\mathrm{W} / \mathrm{C}\end{array}$ & \multicolumn{4}{|c|}{ 単位量 $\left(\mathrm{kg} / \mathrm{m}^{3}\right)$} & $\begin{array}{c}\text { 混和剂 } \\
\text { 添加率 }\end{array}$ \\
\hline \hline $60 \%$ & $\mathrm{~W}$ & $\mathrm{C}$ & $\mathrm{S}$ & $\mathrm{G}$ & $\mathrm{C} \times 1.0 \%$ \\
\hline \hline
\end{tabular}

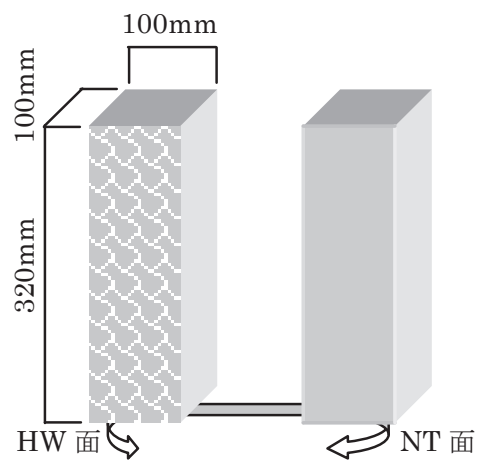

超高圧水洗浄 下地処理なし 下地コンクリート表面処理

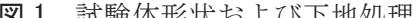

$$
\text { ワイヤストレインゲージ }
$$

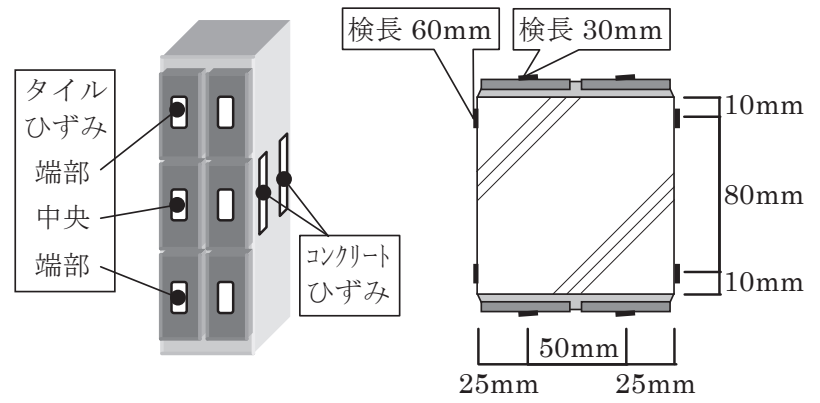

図 2 ひずみ計測位置
は、タイル施工から 2 週間の封縅養生の後に開始した。

ひずみ計測位置を図 2 に示す。ひずみは、コンクリート面に 4 点 と各タイルに 1 点の計 16 点で、載荷軸力方向にひずみゲージを貼 付して計測した。タイルひずみと対比する際の下地コンクリートひ ずみは、コンクリートのひずみ分布が試験体の載荷軸力方向には一 様で、断面方向には平面保持されているものと仮定し、各計測点で 得られた值からタイルのひずタ計測位置直下における下地表面の值 を算出して用いた。

(a) クリープ追従性試験方法

クリープ追従性試験では、タイル仕上げを施したコンクリート角 柱試験体をクリープ試験機に組み込んで 3 ケ月間連続載荷し、その 間の下地コンクリートとタイルのひずみを計測した。試験体の養生 環境は、気温 $20^{\circ} \mathrm{C}$ 、湿度 $60 \%$ とした。載荷開始時と終了時のコン クリート材齡は 42 日と 144 日であったが、試験体と同一養生した 供試体 $(\phi 100 \times 200 \mathrm{~mm})$ の各材齢強度は $32.3 \mathrm{~N} / \mathrm{mm}^{2}$ と $32.0 \mathrm{~N} / \mathrm{mm}^{2}$ であり、この間の強度変化は見られなかった。また、載荷開始時と 終了時の張付材の材齢は 14 日と 116 日であり、モルタル供試体 $(\phi$ $50 \times 100 \mathrm{~mm}$ 、封縅養生）の材齢 28 日と 122 日の強度は $42.0 \mathrm{~N} / \mathrm{mm}^{2}$ と $42.1 \mathrm{~N} / \mathrm{mm}^{2}$ であった。試験体に作用する応力は、載荷開始時の コンクリート強度 $\left(=32.3 \mathrm{~N} / \mathrm{mm}^{2}\right)$ の $1 / 3$ とし、コンクリートの断 面積から載荷荷重を $108 \mathrm{kN}$ とした。なお、載荷期間中の荷重は口 ードセルによって計測し、設定值の $\pm 2 \%$ 以内であるように管理した。 載荷状況を写真 1 に示す。
（載荷状況全景）

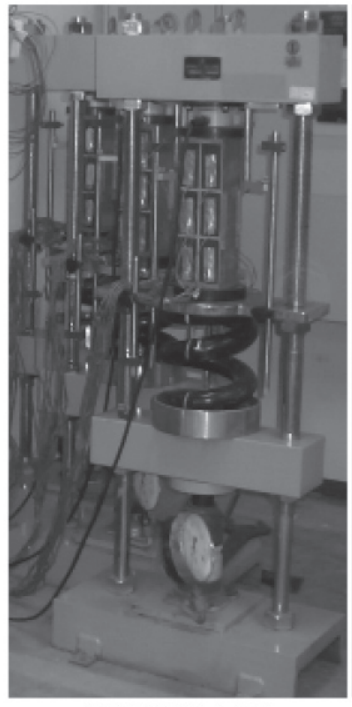

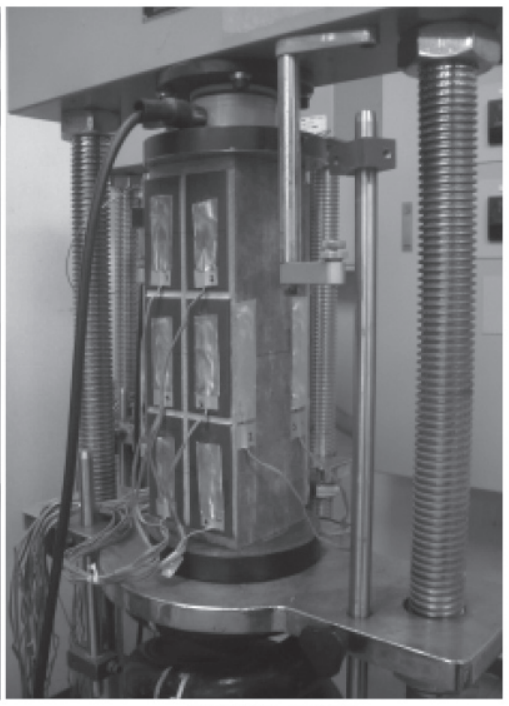

(試験体詳細)
写真 1 クリープ追従性試験載荷状況

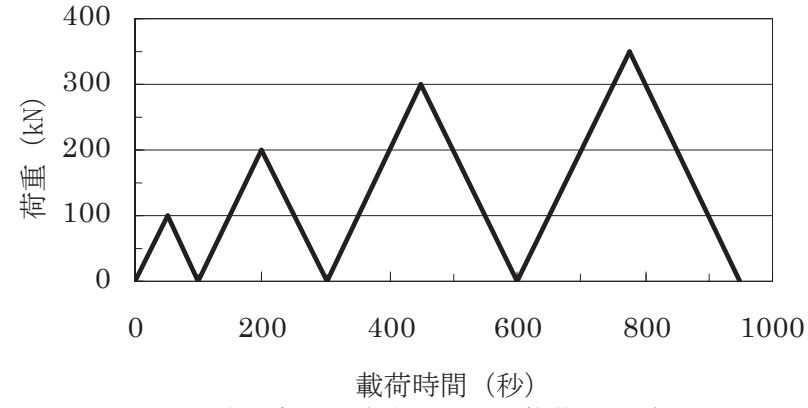

図 3 ひずみ追従性試験における載荷スケジュール 
(b) ひずみ追従性試験方法

ひずみ追従性試験は、アムスラー型万能試験機を用いて試験体を 圧縮載荷し、載荷中の下地コンクリートとタイルのひずみを計測し た。載荷スケジュールを図 3 に示す。載荷時には、最大荷重に至る までの荷重を 4 段階に分け、荷重が各段階に至る都度除荷して繰り 返し載荷した。載荷荷重は、コンクリートが圧壊しない範囲として 最大 $350 \mathrm{kN}$ までとし、載荷速度をコンクリートの圧縮強度試験方 法 JIS A 1108 に定められている $0.6 \pm 0.4 \mathrm{~N} / \mathrm{mm}^{2} /$ 秒の下限值である $0.2 \mathrm{~N} / \mathrm{mm}^{2} /$ 秒とした。

\section{3 実験結果と考察}

(a) クリープ追従性試験結果

乾燥収縮によって生じた下地コンクリートのひずみとタイルのひ ずみの関係を図 4 に示す。乾燥収縮は、ひずみ追従性試験用に製作 した 3 体の試験体で計測し、タイルのひずみは各下地処理面から中 央と端部のタイル各 1 枚の計 12 点を計測対象とした。下地コンク リートの乾燥収縮ひずみは平均 $269 \mu$ であった。下地コンクリート のひずみは計測点によって異なったが、タイルのひずみには大きな 差が無いため、これは張付材の厚さなどによって仕上げ層による拘 束度合いが異なったことなどによると考えられる。ここで、下地コ ンクリートのひずみに対するタイルのひずみの比を既往の研究 1)に 倣い「ひずみ伝達率」と称する。乾燥収縮におけるひずみ伝達率は 平均 0.64 で、計測期間中はほぼ一定であった。

クリープ追従性試験における下地コンクリートのひずみの履歴を 図 5 に示寸。これ以降、凡例に特記したものを除き、図には全ての 試験体の計測結果を記し、図中のひずみは収縮を正として表記する。 ひずみは、載荷期間中に平均で $260 \mu$ から $842 \mu$ に増進した。この 内、乾燥収縮ひずみを除く $313 \mu$ がクリープひずみであり、本試験 体のクリープ係数は 1.2 であった。

クリープ追従性試験によって生じた下地コンクリートとタイルの ひずみの関係を図 6 に示す。ひずみ伝達率は、試験開始直後に期間 中で最も大きな值を示した。試験開始直後のひず夕伝達率は平均 0.64 で、乾燥収縮のみが作用寸る場合とほぼ同じであった。

タイルのひずみが減少に転じた時の下地コンクリートひずみを既 往の研究 1)に倣い「破壊ポイント」と称する。下地処理の有無によ る比較では、下地処理なしの試験体では半数以上のタイルで破壊ポ イントが計測された。一方、超高圧水洗浄した試験体では、タイル のひずみの減少はほとんど見られず、下地処理によって剥離に対す る抵抗性が向上することが確認できた。なお、破壊ポイントを超え てタイルひずみの計測值が 0 になったタイルでは張付材料の側面に ひび割れが観察され、剥離が生じていることが推測できた。

タイルの張付位置による比較では、端部タイルの方が中央タイル よりも小さな下地コンクリートひずみで破壊ポイントを示しており、 タイルの剥離が端部タイルから始まる様子が窥える。その一方で、 中央タイルが破壊ポイントを示した時点でも、ひずみが減少に転じ ていない端部タイルがあった。これは、どちらか片側の端部タイル が剥離することによって、残った端部タイルと中央タイルの応力状 態の差がなくなり、中央タイルが先に剥離したためと考えられる。

(b) ひずみ追従性試験結果

ひずみ追従性試験の繰り返し載荷によるひずみ履歴の例を図 7 に 示す。下地コンクリートとタイルのひずみの関係は、下地コンクリ

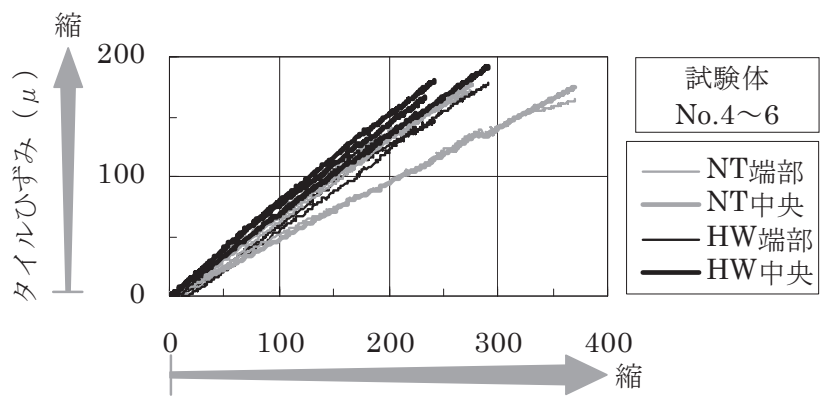

下地コンクリートひずみ $(\mu)$

図４ひずみ追従性試験体の乾燥収縮による試験前ひずみ

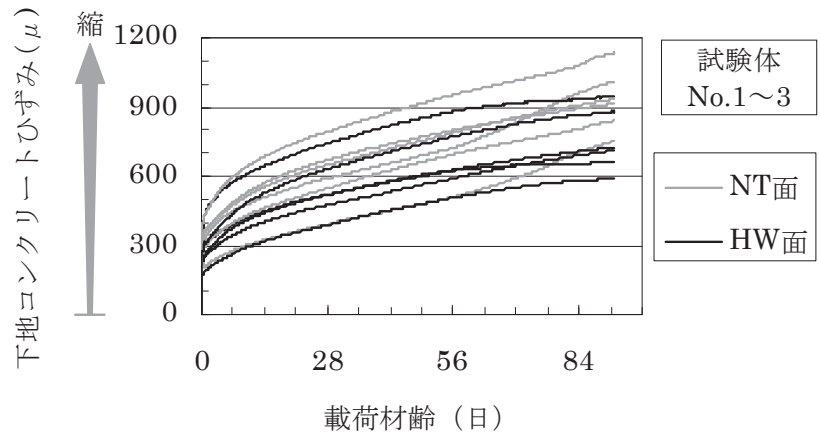

図 5 クリープ追従性試験時下地コンクリートひずみ履歴

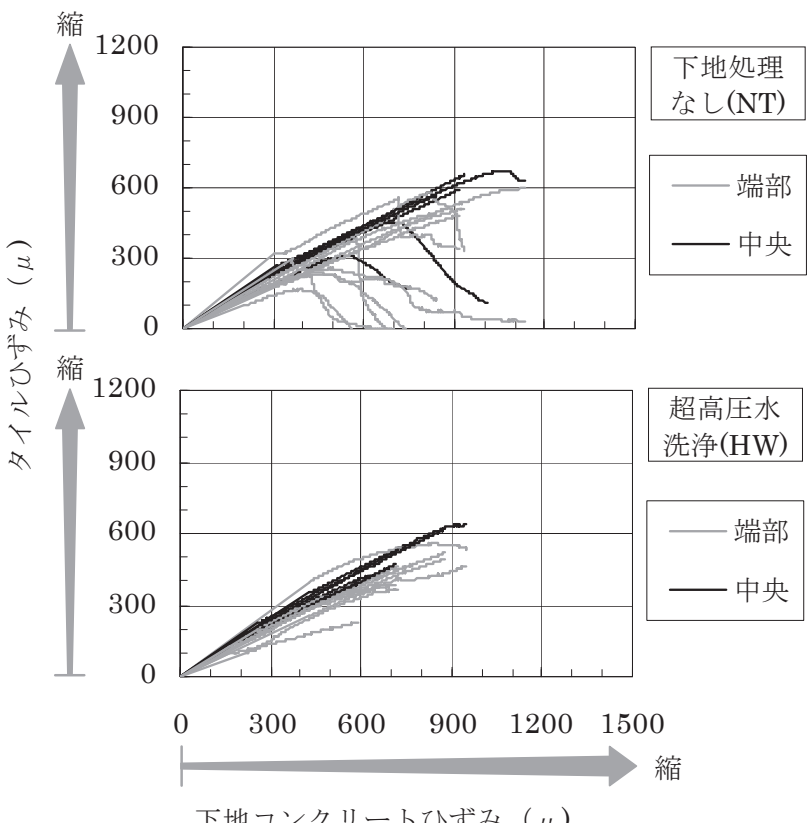

図 6 クリープ剥離試験結果

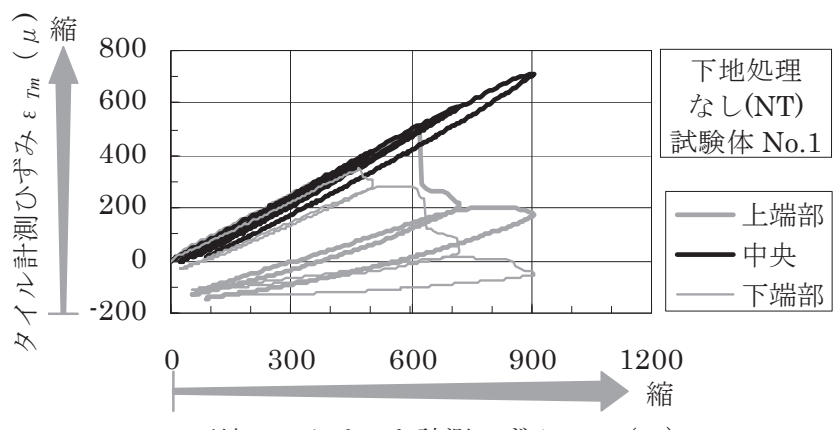

下地コンクリート計測ひずみ $\varepsilon \mathrm{Cm}(\mu)$

図 7 ひずみ追従性試験繰り返し載荷時のひずみ履歴例 
ートのひずみが破壊ポイントを上回った後でも、繰り返し載荷によ る再載荷で除荷直前の状態と同じ関係を示寸再現性があることが確 認できた。このため、ひずみ追従性試験結果は、最大值の包絡線で 示すこととした。

ひずみ追従性試験では、タイルのひずみ計測值がタイル剥離によ って負の值を示した。これは、載荷開始前の乾燥収縮による影響と 見られる。ひずみ追従性試験においては、載荷開始前に生じる試験 体のひずみ評価が重要であり、本来は、ひずみ追従性試験前の試験 体では乾燥収縮を生じない養生を行うべきであると考えられる。し かし、ここではクリープ試験中の乾燥による収縮を計測した後の試 験体を使用したため、ひずみ追従性試験中の下地コンクリートと夕 イルの計測值に対して、載荷開始前の乾燥収縮ひずみによる影響を 考慮して、式(1),(2)による補正を行った。

$$
\begin{aligned}
& \varepsilon_{C}=\varepsilon_{C m}+\varepsilon_{D} \\
& \varepsilon_{T}=\varepsilon_{T m}+\alpha_{0} \times \varepsilon_{D} \\
& \text { ここに、 } \\
& \begin{array}{ll}
\varepsilon_{C} & : \text { 下地コンクリート全ひずみ } \\
\varepsilon_{T} & : \text { タイル全ひずみ } \\
\varepsilon_{C m} & : \text { ひずみ追従性試験中に生じた下地コンクリート計 } \\
& \text { 測ひずみ } \\
\varepsilon_{T m} & : \text { ひずみ追従性試験中に生じたタイル計測ひずみ } \\
\varepsilon_{D} & : \text { 載荷試験前乾燥収縮ひずみ } \\
\alpha_{0} & : \text { 載荷試験初期ひずみ伝達率 }
\end{array}
\end{aligned}
$$

補正に当たって、タイルのひずみを正しく算出するためには、計 測値に対して乾燥収縮時のタイルひずみ、もしくは、乾燥収縮時の ひずみ伝達率を用いて補正することが必要である。しかし、ここで は載荷速度による影響を比較することを目的としているため、載荷 開始前のひずみについてもひずみ追従性試験と同様に生じたものと 見なして、載荷試験における初期ひずみ伝達率を使用してタイルの 全ひずみを算出した。

ひずみ追従性試験結果を図 8 に示す。ひずみ追従性試験で下地コ ンクリートに与えた最大ひずみは、クリープ追従性試験よりも大き く、平均で $1173 \mu$ であった。これによって、下地処理を行わなかっ た試験体では、全ての端部タイルと $1 / 3$ の中央タイルで破壊ポイン トが計測された。また、超高圧水洗浄した試験体でも、半数以上の 端部タイルで破壊ポイントが計測された。破壊ポイントの比較から、 ひずみ追従性試験でもクリープ追従性試験と同様に、タイルの剥離 は端部タイルから始まる様子が窺えた。また、下地処理によって剥 離に対する抵抗性が向上することが確認できた。

(c) 載荷速度による相違

クリープ追従性試験とひずみ追従性試験から得られた初期ひずみ 伝達率と破壊ポイント発現割合の比較を表 4 に示す。ひずみ追従性 試験による初期ひずみ伝達率は平均 0.80 で、クリープ追従性試験よ りも $25 \%$ 大きい傾向にあった。これは、クリープ追従性試験ではひ ずみを与えられる期間が長いことにより、張付モルタル層内でせん 断変形に対するクリープが生じるためと考えられる。

破壊ポイントは、試験終了時まで発現しないタイルもあったため

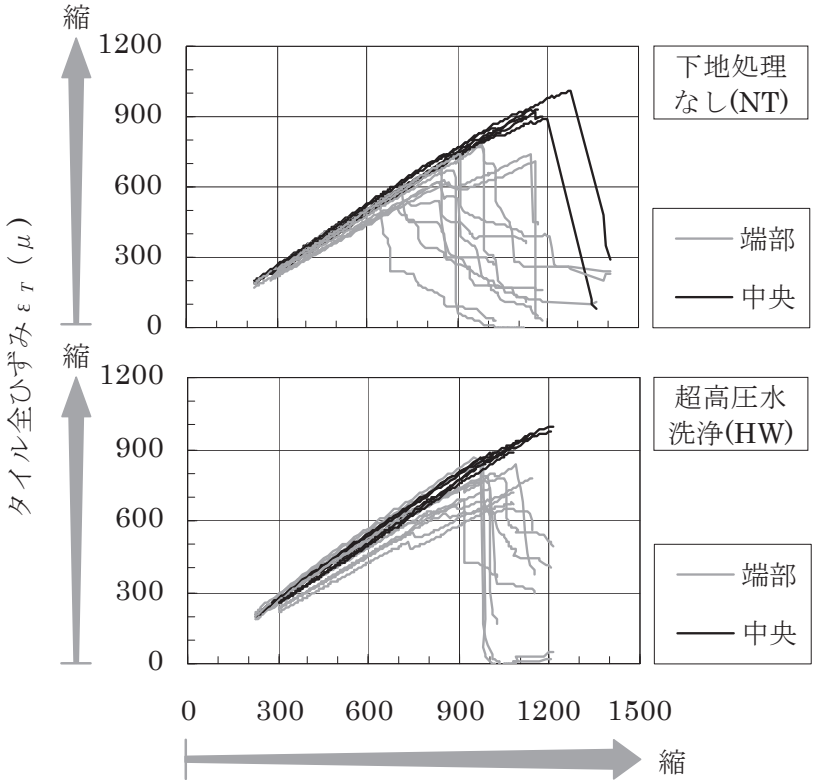

下地コンクリート全ひずみ $\varepsilon_{C}(\mu)$

図 8 ひずみ追従性試験結果

表 4 最大ひずみ伝達率と破壊ポイント発現割合の比較

\begin{tabular}{|c|c|c|c|c|c|}
\hline \multirow{2}{*}{} & \multicolumn{2}{|c|}{ クリープ追従性試験 } & \multicolumn{2}{c|}{ ひずみ追従性試験 } \\
\cline { 3 - 6 } \multicolumn{2}{|c|}{} & $\mathrm{NT}$ & $\mathrm{HW}$ & $\mathrm{NT}$ & $\mathrm{HW}$ \\
\hline \multirow{2}{*}{$\begin{array}{c}\text { 初期ひずみ } \\
\text { 伝達率 }\end{array}$} & 平均 & 0.63 & 0.65 & 0.81 & 0.79 \\
\cline { 2 - 6 } & 標準偏差 & 0.11 & 0.10 & 0.05 & 0.06 \\
\hline 破壊ポイン & $600 \mu$ 以下 & $7 / 18$ & $0 / 18$ & $0 / 18$ & $0 / 18$ \\
\hline \multirow{2}{*}{ ト発現割合試験終了時 } & $11 / 18$ & $1 / 18$ & $12 / 18$ & $8 / 18$ \\
\hline
\end{tabular}

平均值を計算することはできないが、最小のものでは、ひずみ追従 性試験では下地処理なしが $636 \mu$ 、超高圧水洗浄したもので $915 \mu$ であるのに対して、クリープ追従性試験では下地処理なしが $361 \mu$ 、 超高圧水洗浄したもので $852 \mu$ であり、クリープ追従性試験ではひ ずみ追従性試験よりも破壊ポイントが小さくなる傾向が見られた。 また、同じ下地コンクリートひずみにおける破壊ポイントの発現率 を比較すると、ひずみ追従性試験よりもクリープ追従性試験の方が 高くなった。この原因として、載荷を開始した材齢の違いによる影 響も考えられるが、張付材の強度にはクリープ試験時に破壊ポイン トが発現し始めた時期からひずみ追従性試験時までの間で大きな変 化は無かった。一方、長期の載荷環境下のコンクリートなどでは、 静的載荷で得られた強度よりも小さな值でクリープ破壊が生じるこ とから、これは、載荷時間が長いクリープ追従性試験では、与えら れたせん断応力で張付モルタルにクリープ破壊が生じることが主た る原因であると考えられる。

クリープ追従性試験では、破壊ポイント以降の下地コンクリート のひずみの増進に対してタイルのひずみは徐々に小さくなり、接着 面の破壞が徐々に進行する様子が窺える。これに対して、ひずみ追 従性試験におけるタイルのひずみは破壊ポイント以降に急減する傾 向にあった。これは、タイルのひずみ伝達率が低下寸ることによっ て、下地コンクリートに軸力が再分配されてひずみが増大し、更な るひずみ伝達率の低下を生じるサイクルが、高応力下ほど急激に進 行するためと考えられる。

これらのことから、タイル仕上げの長期にわたる接着性能を評価 
するためには、載荷速度についての考慮が必要であることがわかっ た。クリープ追従性試験は、従来の試験方法よりも実建物に近い評 価ができると考えられる。また、従来のひずみ追従性試験では危険 側の評価となり易いが、載荷開始前に生じるひずみや載荷速度の相 違による差を考慮することで、より実建物に近い状態における評価 ができると考えられる。本実験の範囲では、長期にわたってひずみ が進行する場合を評価するためには、ひずみ伝達率はひずみ追従性 試験で得られる值の 8 割程度とする必要がある。

\section{3.タイルのひずみ追従性と接着性能の関係}

\section{1 実験目的}

クリープ追従性試験やひずみ追従性試験では、破壊ポイントが下 地処理によって増大する結果が得られた。しかし、破壊ポイントが 計測されたタイルでも剥離を生じたものとそうでないものがあり、 破壊ポイントだけではタイル仕上げの剥離抵抗性を適切に示すこと が出来ていない。タイル仕上げの剥離防止を評価するためには、破 壊ポイント以上のひずみを生じた下地コンクリートに対して、タイ ルが維持する接着性能を把握することが重要と考えられる。そこで、

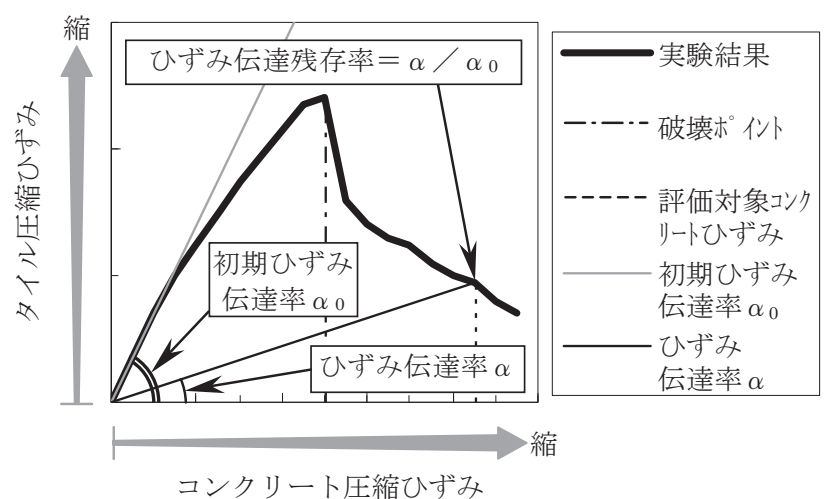

図 9 ひずみ伝達残存率の概念
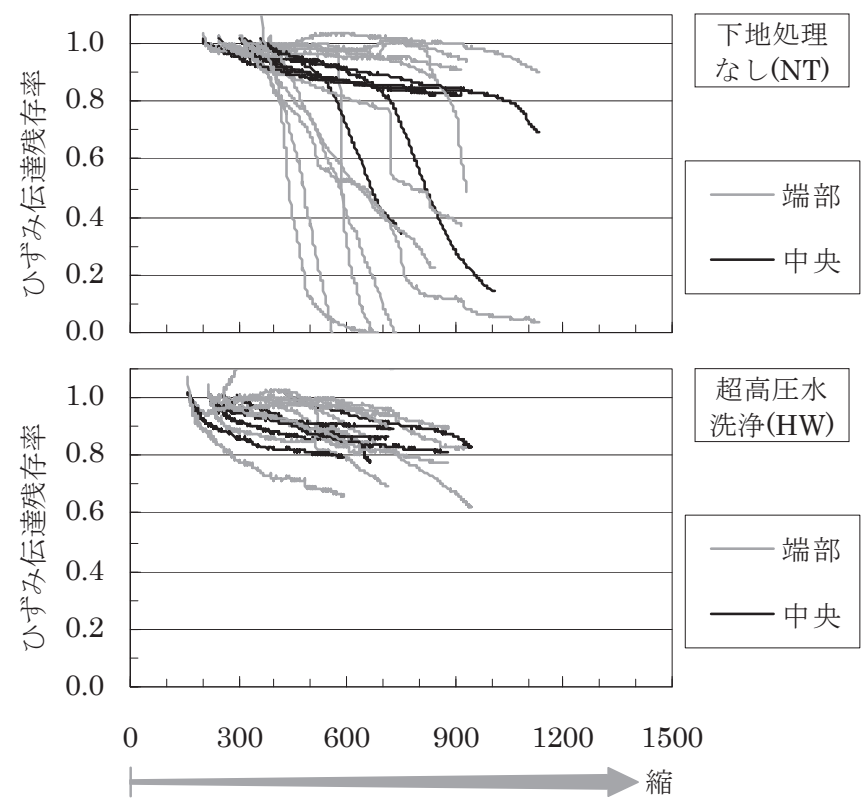

下地コンクリートひずみ $(\mu)$

図 10 クリープ追従性試験におけるひずみ伝達残存率
クリープ追従性試験やひずみ追従性試験の結果から、ひずみの進行 によりタイルの接着性能の低下度合いを評価する方法を提案する。 また、これによって得られる值とタイル仕上げの接着強度の関係を 実験で把握し、タイル仕上げの剥離抵抗性の評価が可能であること を検証する。

\section{2 タイルの剥離抵抗性評価方法の提案}

破壊ポイントを過ぎた試験体でも、ひずみが残留しているタイル は完全な剥離には至っていないため、剥離に対する抵抗性が残って いると考えられる。また、ひずみ伝達率は破壊ポイントを過ぎた後 でも繰り返し載荷に対する再現性があり、下地コンクリートに対す るタイル仕上げのひずみ追従性の評価指標として使用することが可 能と考えられる。しかし、ひずみ伝達率は、使用する材料や施工方 法によって数值が異なる。そこで、ひずみ伝達率を剥離に対する抵 抗性の評価指標として標準化するため、クリープ追従性試験やひず み追従性試験の任意の時点におけるひずみ伝達率の、初期ひずみ伝 達率に対する割合を「ひずみ伝達残存率」と定義した。ひずみ伝達 率とひずみ伝達残存率の関係を図 9 に示す。

クリープ追従性試験におけるひずみ伝達残存率の履歴を図 10 に、 ひずみ追従性試験におけるひずみ伝達残存率の履歴を図 11 に示す。 ひずみ伝達残存率は、破壞ポイントに至らない試験体においても下 地コンクリートのひずみの増大に伴って徐々に低下した。この傾向 は、クリープ追従性試験で特に顕著であり、長期的な加力下では張 付材料のクリープによってタイル仕上げのひずみ伝達率が低下寸る ことを示していると考えられる。

\section{3 実験方法}

クリープ追従性試験とひずみ追従性試験を行った後の試験体に対 して、建研式接着力試験器によるタイル仕上げの接着強度試験を行 い、提案した評価方法のひずみ伝達残存率との相関を検討した。

\section{4 実験結果と考察}

タイル仕上げのクリープ追従性試験やひずみ追従性試験結果と接
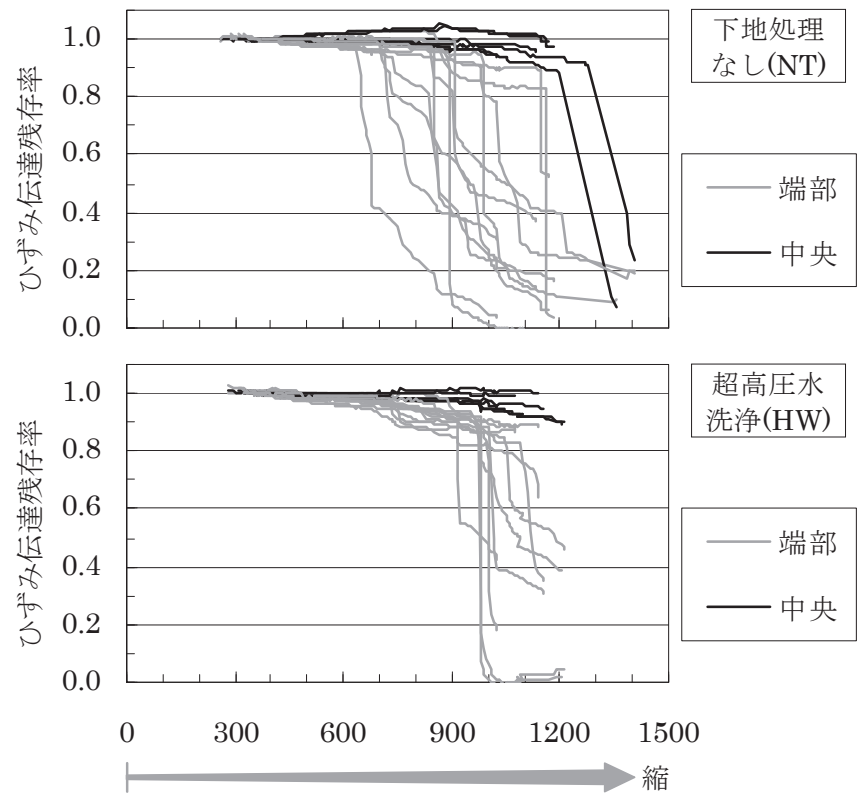

下地コンクリートひずみ $(\mu)$

図 11 ひずみ追従性試験におけるひずみ伝達残存率 


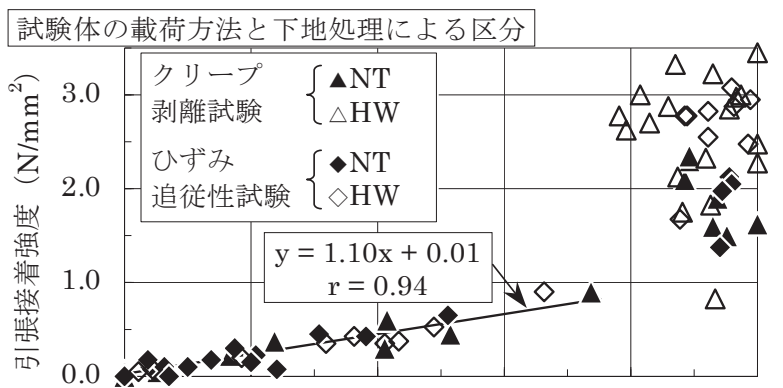

接着強度試験結果の破断位置による区分

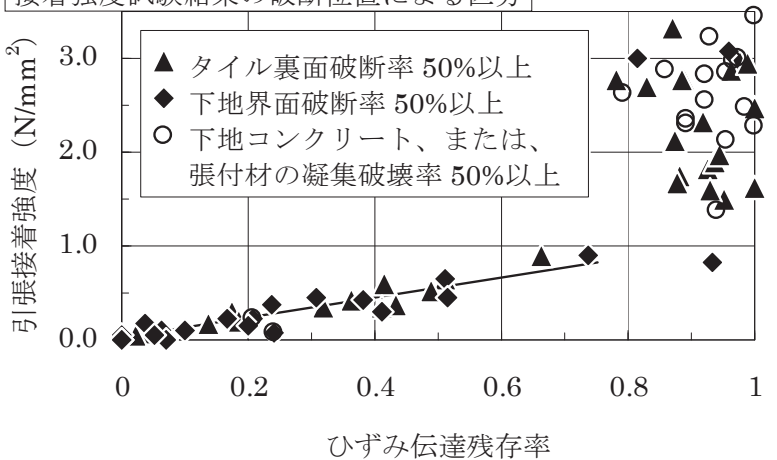

図 12 ひずみ伝達残存率と引張強度試験結果の関係

着強度の関係を図 12 に示す。図中のひずみ伝達残存率は、クリー プ追従性試験やひずみ追従性試験によってタイルの接着性能が劣化 した状態を示すものとして、各試験における最終值を使用し、ひず み伝達残存率が計測誤差から 0 末満になった場合や 1 を超えた場合 には、それぞれの值を 0,1 とした。また、接着強度試験結果の破断 位置の凡例は、タイルの張付面積に対して過半を占める破断位置に よって区分した。

ひずみ伝達残存率が 0.75 以上のタイルでは破壞ポイントは発現し ておらず、接着強度は $0.8 \mathrm{~N} / \mathrm{mm}^{2}$ 以上の広範囲に分布していた。一 方、ひずみ伝達残存率が 0.75 を下回ったものでは全てで破壊ポイン トが発現し、接着強度は $0.9 \mathrm{~N} / \mathrm{mm}^{2}$ を下回った。ひずみ伝達残存率 と接着強度の関係は、ひずみ伝達残存率が 0.75 以上の場合は相関が 見られないが、ひずみ伝達残存率が 0.75 未満の範囲では比例関係に あり、この範囲では、クリープ追従性試験とひずみ追従性試験のい ずれの場合でも、下地処理の方法に関わらず、接着強度とひずみ伝 達残存率は相関係数が 0.94 となる高い相関を示した。

接着強度試験時の破断位置は、破壊ポイントが計測されない範囲 では様々な破壊状態が混在する結果であったが、破壊ポイントが計 測されたものでは張付材と下地コンクリート、もしくは、タイルと の界面における破断が大半を占める結果となった。

引張試験では圧縮試験とは異なり、微細なひび割れや気泡などが 弱点となって材料本来の強度よりも低い值を示寸場合がある。この ため、破壞ポイントが計測されない範囲では多様な破壊状態を示し て強度試験結果に相関が現れなかったと考えられる。一方、破壊ポ イントが計測されたものでは、ひずみが界面近傍に損傷を与えるこ とによって、引張試験時の界面破断を生じ易くさせるとともに、ひ ずみ伝達残存率を低下させるために相関が観察されたものと考えら れる。なお、タイル仕上げの接着強度の基準值 ${ }^{899)}$ である $0.4 \mathrm{~N} / \mathrm{mm}^{2}$ を上回るものの中でも、破壊ポイントが計測されて接着強度が急激
に低下したものがあるため、この值を維持していることは必ずしも 接着性能が初期の状態を保っていることを示寸ものではないことが 分かった。

以上の結果から、材料や施工方法によるタイルの下地追従性や接 着強度とひずみ伝達残存率の関係を把握することによって、下地コ ンクリートに生じるひずみの大きさから、破壊ポイント以降のタイ ル仕上げの接着強度の低下傾向を推測することが可能になると考え られる。

\section{4.まとめ}

タイル張り仕上げの剥離防止性能の評価に用いられているひずみ 追従性試験について、ひずみを与える際の載荷速度による影響を確 認するとともに、ひずみ追従性試験で得られる結果とタイルの接着 性能の関係について実験的検討を行った。その結果、主に以下のこ とが明らかになった。

(1)クリープ追従性試験における初期のひずみ伝達率は、無載荷で乾 燥収縮ひずみが作用する場合とほぼ同じである

(2)載荷時間が短いひずみ追従性試験では、ひずみが長期にわたって 進行する場合に比べて、ひずみ伝達率や破壊ポイントの值が大き くなる

(3)本研究で定義したひずみ伝達残存率を用いることによって、下地 コンクリートのひずみの大きさから、タイル仕上げの接着強度の 低下傾向を推測することが可能になる

\section{謝辞}

本研究を進めるにあたり、実験に御協力頂いた日本化成㑣の守屋 氏と竹中氏に感謝の意を表します。

\section{参考文献}

1）名知博司,小野正：外装タイル張り仕上げのひずみ追従性設計法の提案, 日本建築学会構造系論文集,第 615 号,pp31-37,2007.5

2）三枝一仁,馬場明生,前田孝一,山崎健一,松島泰幸,渡辺博司：タイル直張 り工法の安全性に関する研究（その 2 躯体の歪に対する追従性の実験）, 日本建築仕上学会,大会学術講演会研究発表論文集,pp205-208,1993.9

3）名知博司,小野正: タイル直張り仕上げのひずみ追従性に及ぼすタイル要 因の影響,日本建築学会構造系論文集,第 563 号,pp15-22,2003.1

4）名知博司,小野正:外装タイル張り仕上げのひずみ追従性および引張接着 強度に及ぼす下地処理要因の影響, 日本建築学会技術報告集,第 19 号, pp $15-18,2004.6$

5) 伊藤学, 渡邊康則,永尾弘孝, 高松誠 : ヤング係数が低いポリマーセメント 系タイル張付け材の開発 その 2 下地要因と繰返し応力、せん断応力の影 響, 日本建築学会大会学術講演梗概集.A-1,pp741-742,2004.8

6）佐々木仁,添田智美,中山昌尚,高山勝行：外装タイル仕上げにおける剥離 防止性能に関寸る基礎実験 その 1 タイル先付け仕上げの単調圧縮載荷試 験, その 2 温度ひずみ解析に基づいた繰り返し型ひずみ追従性試験法の提 案, その 3 直張り仕上げの繰り返し型ひずみ追従性試験結果, 日本建築学 会大会学術講演梗概集.A-1,pp689-694,2007.8

7）稲葉洋平,佐々木正治,閑田徹志,巴史郎：外壁タイルの付着性能に関する 検討 その 3 追従性試験, 日本建築学会大会学術講演梗概集.A-1,pp695-696, 2007.8

8）国土交通省大臣官房官庁営繕部：公共建築工事標準仕様書（平成 22 年 版）,建築工事編

9）日本建築学会 : 建築工事標準仕様書・同解説 JASS19 陶磁器質タイル張 り工事, 1996.10 